\title{
STUDENT ENGAGEMENT AND MOTIVATION IN A VOCATIONAL ENGLISH PROJECT BASED LEARNING
}

\author{
Arik Susanti $^{1}$, Anis Trisusana ${ }^{2}$ \\ ${ }^{1}$ Universitas Negeri Semarang, Indonesia \\ 1ariksusanti@unesa.ac.id \\ ${ }^{2}$ Universitas Negeri Semarang, Indonesia \\ ${ }^{2}$ anistrisusana@unesa.ac.id
}

\begin{abstract}
This study aimed to describe the student engagement and motivation in studying English through Project Based Learning (PjBL). PjBL provides students the freedom to be critical thinkers and problem solvers. Moreover, it places the students in situations that require authentic use of language in order to communicate and to present. The method used was qualitative since the objective of the research was to describe the development of the students' creativity. The participants were 40 students and 2 English teachers in Vocational High Schools in East Java Province. The data were gained through interview and classroom observation. The data from interview were transcribed and analyzed qualitatively, and the data from classroom observation were coded and analyzed qualitatively. The results showed that PjBL could increase the students' motivation. The students were interested in completing their projects and enthusiastic in learning English. Therefore, PjBL is recommended to be used in English learning to encourage the student engagement and motivation.
\end{abstract}

Keywords: student engagement and motivation, project based learning, vocational English

\section{INTRODUCTION}

Nowadays, the world has globalized and it has been easier for people to build business relationship over the world. It means that every field of business will require high qualified human resources. People will try to be the best in their field. Considering the world expansion, it is needed both life skills and soft. English is one of the soft skills needed by human in our country, Indonesia, since it is as international language. Knowing the importance of English, in Indonesia English is taught from primary school up to university level. It is expected that the students are able to communicate English so they have soft skill to compete in the globalization era.

However, there are many problem faced by the students, especially the students in Vocational High School. Most of them think that English is difficult subject so that they do not have any motivation to study English. They do not have any interest to learn. The students think that they do not need to study English since they do not want to continue their study. They only hope that they will get a good job. Moreover, it is also caused by the process of teaching learning. Most of Indonesian English teachers dominate the class and give less exposure to English. The teachers still apply the product-oriented in the teaching of English. Whereas, it is known that learning English takes time and needs a process. Williams (2003) argues that the process model proposes that a good performance in English is the result of the complex interaction of activities that include several stages of development. However, it must be noted that learning listening, reading and speaking is also required as complementary skills to the language learners. 
To overcome that problem, the teachers should encourage the students to have a result of their language learning. It is believed that motivation is one of the most important factors that determine the rate and success of second language attainment. It will provide the primary impetus to initiate learning English and force to sustain the long and often tedious learning process for many learners. Without having sufficient motivation, the students cannot accomplish long-term goals.

To make the students 'motivation, the teacher should change the method of teaching learning. One of the method that can be used to motivate the students is project based learning. Project Based Learning is a model based on constructivist approach that involves students in learning materials through an self-regulating inquiry process. Through this method, students have a tendency to be active since the students have to choose topic, search information, forming concept, develop thought present the project until they evaluate and reflect their work by themselves. Besides, by using Project Based Learning, the learners are included in interactive an intentional communication to complete the project so that they have the opportunity to use the language in the real context (Richards et al., 2002). The activity that students can do is sharing their ideas to plan and construct the way to complete their project. The attainment of the Project Based Learning method application has been reported by several researchers (García, 2016; Tamim et al., 2013; Wurdinger et al., 2007) and they can motivate the students. Seeing the success of Project Based Learning, this study tries to describe how Project Based Learning can motivate the students in studying English.

\section{METHODS}

\subsection{Participants}

40 students were selected at random to take part in the research. The students were vocational high school and had learnt English for almost 2 years in high school so that their English competences are in early intermediate. When they were learning English, they focused in 4 skills of English such reading, listening, speaking and writing. Two teachers who had been teaching English using the text book ESP designed by the teachers of English Division in mechanical engineering and English language Department, UNESA) were invited to join in the research.

\subsection{Instruments}

The tools used for the study were observation sheet, questionnaire and interview.

\subsection{Procedures}

The time for data collection lasted during one month of the first semester of the school year 2017-2018. Students may have an overview on the difficulties of learning English in the second year at vocational high school. During four weeks, the classroom performance by 2 teachers was observed. The detailed note were kept and interpreted, and then the conclusion were drawn out. After classroom observation was done, three students were chosen to join in interview. The interview was constructed open-ended questions. The data were recorded, transcribed and translated in English. The last week, the questionnaires were delivered to 40 second year mechanical engineering major students. The students had 15 minutes to complete the questionnaire. The purpose and importance of the study were explained. While students were completing the questionnaires, any questions were clarified by the teacher. 


\section{FINDINGS AND DISCUSSION}

Motivations possessed by the second year mechanical engineering major students at Vocational High School.

Table 1: The Students' Motivation to Learn English

\begin{tabular}{|c|c|c|c|}
\hline No & Reasons & Number & Percentage \\
\hline 1 & To get a job in the future & 38 & $95 \%$ \\
\hline 2 & To communicate with foreigners & 15 & $38 \%$ \\
\hline 3 & $\begin{array}{l}\text { To study the people, culture of English speaking } \\
\text { countries }\end{array}$ & 20 & $50 \%$ \\
\hline 4 & $\begin{array}{l}\text { To read newspapers, watch TV programs, listen to } \\
\text { music ... in English }\end{array}$ & 10 & $25 \%$ \\
\hline 5 & To live and study abroad & 5 & $13 \%$ \\
\hline 6 & English is a compulsory subject & 3 & $8 \%$ \\
\hline 7 & To get good marks in the exam & 15 & $38 \%$ \\
\hline
\end{tabular}

A questionnaire was conducted among 40 students to find out the reason why students learn English. 95\% of them- the highest percentage identified the major reason for learning English was to get a job in the future. The reason for this was that most of the students want to get a job in foreign company so that they must have English competency. Moreover, nowadays Indonesia has applied free trade to support ASEAN Economic Community. They have to use much English in communicating in their job field. In addition, $50 \%$ of the students wants to study abroad, learn English culture, and they are able to speak in English. Half of the students in vocational high school want to continue their higher education in abroad. Based on the interview, some of the students also say that they like to study English culture to improve their knowledge. The same number of the students, 38\% of the students, perceived that they want to learn English because they have motivation to get good marks in English exam and they are also able to speak with foreigners. In their opinion, they think if they have better score in English examination they are able to communicate with strangers and finally they will get better job and avoid culture shock as well as difficulties in communicating. Only 3 out of 40 students claimed that they studied English because it is a compulsory subject. Sum up, it can be said that the main types of motivation the students had learnt English because of their future and they want to continue their study and they finally can communicate and understand English better.

\section{PROJECT BASED LEARNING TO MOTIVATE THE STUDENTS IN LEARNING ENGLISH}

In order to find out the answers to this question, observation classroom was conducted when the teacher was teaching English especially in teaching writing. The observation concentrated on activities and techniques employed by the teachers in the process of teaching learning writing. Among the observation, the teacher divided the process of teaching into three parts namely pre-teaching, whilstteaching and post teaching. In the pre teaching activities, the students are motivated by the teacher such as giving a picture to encourage their readiness. In this step, the teacher also mentioned the learning objective achieved by the students. Preteaching is a kind of activity to warm up the students so that they are ready to study English.

There are many activities applied by the teacher in whilst teaching activity including individual work, pair work and group work was mostly used by the teacher. In this step, the teacher will ask the students to do several steps. In 
identifying the real problem, the teacher asked the students to read the text about technology. After that, they would fill the graphic organizer that had been prepared by the teacher. In this step, the students did it individually. Here, all the students were encouraged to present their result. Then, they could study in group work when they want to finish their project. The students were asked to create wall magazine done in group. Here are the students' activities to motivate them in learning English, especially in writing.

Table 2: The Students'Activity in the Process of Teaching Learning

\begin{tabular}{|c|c|c|}
\hline Category & Criteria & $\begin{array}{c}\text { Percentag } \\
\text { e }\end{array}$ \\
\hline \multirow{4}{*}{ Able to work with group } & Able to work with all members very well & $80 \%$ \\
\hline & Able to work with all members well & $75 \%$ \\
\hline & Able to work with all members quite well & $50 \%$ \\
\hline & Able to work with all members but not really good & $20 \%$ \\
\hline \multirow{4}{*}{ Able to give opinion } & All members are very active in giving opinion & $85 \%$ \\
\hline & Some members are active in giving opinion & $60 \%$ \\
\hline & Several members are active in giving opinion & $40 \%$ \\
\hline & Few members are active in giving opinion & $15 \%$ \\
\hline \multirow{4}{*}{$\begin{array}{l}\text { Able to appreciate and accept } \\
\text { the other opinions }\end{array}$} & $\begin{array}{l}\text { All members are able to appreciate and accept the } \\
\text { others opinions }\end{array}$ & $75 \%$ \\
\hline & $\begin{array}{l}\text { Some members are able to appreciate and accept the } \\
\text { other opinions }\end{array}$ & $60 \%$ \\
\hline & $\begin{array}{l}\text { Several members are able to appreciate and accept } \\
\text { but the other ones cannot accept the opinions }\end{array}$ & $50 \%$ \\
\hline & $\begin{array}{l}\text { Few members are able to appreciate and accept but } \\
\text { many of members cannot accept the opinions }\end{array}$ & $25 \%$ \\
\hline
\end{tabular}

Based on the table above, it could be seen that project based learning let the students to appreciate their friends' opinion. When the students finished their proect they must work in group. Here, they learned how to appreciate different opinion. The table showed that $75 \%$ students had given their appreciation when the member of the group giving their ideas. They gave their friends an oppourtunity to read their report writing. They also gave feedback or comment if they did not agree and they also have the solution when their friends made mistakes. $85 \%$ of the students had a brave to express their opinion. By working in the group, the students did not feel any stress since they could express their idea freely in their small group and it would minimize their force from the teacher. Most of them felt enjoyed since the teacher was as facilitator. In addition, the teacher also implemented many kinds of technique that encorage the students to be involved in the process of teaching learning.

After all the students expressed their idea in the form of writing, then they will create wall magazine. This activity also promoted them to be creative. They could share their creativity to make better wall magazine. In short, the teacher has made great effort to motivate the students in learning English. The students 'activity should be promoted by the teacher. Moreover the teacher ought to give a reward for the group of students who could create the best wall magazine. 


\section{CONCLUSION}

It can be concluded that the students motivation in studying English because they want to get a job for their future. $95 \%$ of the students reponded that they wanted to have better life by having good English. Furthermore, they wanted to continue their study in higher education. They were also aware that in ASEAN Economic Community was required high qualified human resources so that they must improve their knowledge of English. To achive the students' goal, the teacher should motivate their students by implementing Project Based Learning. There were many activities that can be applied to reduce their students' stress. The teacher implemented individual work, group work and pair work to motivate the students to learrn English. It showed that it was a good impact toward the students' motivation. They are able to write report text and finally they could create wall magazine that also increase their literacy skill and creativity.

\section{REFERENCES}

ChanLin, L .(2008). Technology Integration applied to project based learning in science. Innovation in Education and Teaching International, 45. 5565

Digest, L. E. (1998). Learning for Adult English Language Project-Based Learning for Adult English Language Learners . ERIC Digest ., 1-7.

Doppelt, Y. (2003). Implementation and Assessment of Project-Based Learning in a Flexible Environment, 255-272.

Ergül, N. R., \& Kargın, E. K. (2014). The Effect of Project based Learning on Students' Science Success. Procedia - Social and Behavioral Sciences, 136, 537-541. http://doi.org/10.1016/j.sbspro.2014.05.371

García, Emma. (2016). The Need to Address Non-Cognitive Skills in the Education Policy Agenda1 Non-cognitive Skills and Factors in Educational Attainment (pp. 31-64): Springer.

$\mathrm{H}$. Roessingh and W. Chambers, - Project-based learning and pedagogy in teacher preparation: Staking out the theoretical mid-ground,\| International Journal of Teaching and Learning in Higher Education, vol. 23, no. 1, pp. 60-71, 2011

Harmer, Jeremy. (2004). How to Teach Writing. England: Pearson Education Ltd.

Keser, H., \& Karahoca, D. (2010). Designing a project management e-course by using project based learning. Procedia-Social and Behavioral Sciences,2(2), 5744-5754.

Koparan, T., \& Güven, B.(2008). The Effect on the 8 th Grade Students' Attitude towards Statistics of Project Based Learning. International Journal of Environmental \& Science Education, 3(3).

Pearlman, B. (2006). New skills for a new century. Edutopla, June, 50-53.

Permatasari, S. F. (2011). Improving Students'Speaking Skill Throuh Project Based Learning for Second Graders of SMPN 1 Kawedanan, Magetan. Malang : University Press

Poonpon, K. (n.d.). ENHANCING ENGLISH SKILLS THROUGH PROJECT-, $X L, 1-10$.

Richards, Jack C, \& Renandya, Willy A. (2002). Methodology in language teaching: An anthology of current practice: Cambridge university press. 
Tamim, S. \& Michael, G (2013) A Case Study: Teacher Implementing Project Based Learning. Thailand: University Press

Wang, B. T., Teng, C. W., \& Lin, Y. H. (2015). Let ' s Go Traveling - ProjectBased Learning in a Taiwanese Classroom, 5(2), 84-88. http://doi.org/10.7763/IJIET.2015.V5.481

Williams, James D. (2003). Preparing to teach writing: Research, theory, and practice: Routledge.

Z.Dornyei. (2001)Teaching and researching motivation, Pearson Education Limited, Edinburgh, 